\title{
Sustainability's Indicators of sheep farming systems in the eastern steppe ecosystem of Algeria.
}

\author{
Boussaada D ${ }^{1}$, Yerou $\mathbf{H}^{1,2}$ \\ ${ }^{1}$ Department of Agriculture, Natural and live science Faculty. University of Mascara 29000. \\ Algeria; \\ ${ }^{2}$ Laboratoire Géo-Environnement et Développement des Espaces (GEDE). University of \\ Mascara 29000. Algeria.
}

Corresponding Author: Houari Yerou, Institute of Agriculture. Natural and live science Faculty. University of Mascara 29000. Algeria; Email: houariyerou@gmail.com

Article history; Received: July 7th 2021; Revised: August 28 $8^{\text {th }}$ 2021; Accepted: January 1 2022

\begin{abstract}
Sheep farming systems in the steppe of M'sila eastern Algeria play a key role in the red meat production chain. The aim of this contribution is to as sess the sustainability of sheep farms in relation to the current functioning of the breeding and to describe the strong and weak points limiting improvement of productivity in a perspective of sustainability. The method of indicators of sustainability of farms (IDEA) was used to evaluate sustainability. The typological results allowed us to distinguish two main types of livestock farming, namely agro pastoral and pastoral, which have different sustainability profiles. The agro pastoral type is characterized by sustainability scores of 69.4/100, 43.6/100 and 36.4/100 respectively for agro ecological, socio-territorial and economic sustainability. The pastoral type shows the same trend with superiority in the econ omic scale. The comparis on of the sustainability scales in relation to the type of livestock showed that the two livestock systems are significantly different for agro-ecological and socio-territorial scale $(\mathrm{P}<0.05)$ in contrast to the economic scale. Consequently, each type requires particular improvements, according to its functioning and the threshold of the scores realized at the level of the global sustainability in order to guarantee a profitability of the breeding at the level of the Algerian steppe region.
\end{abstract}

Keywords : Algeria, meat sheep, sustainability, indicators, rangeland, steppe.

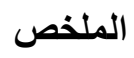

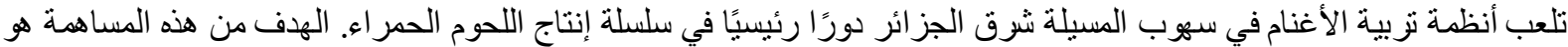

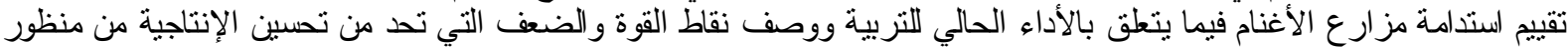

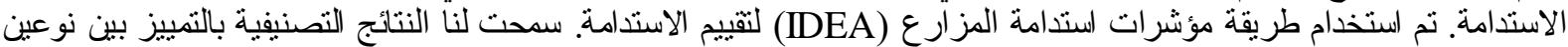

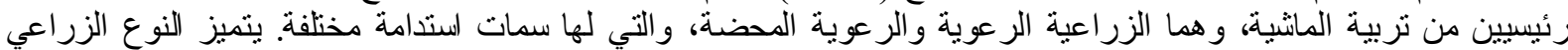

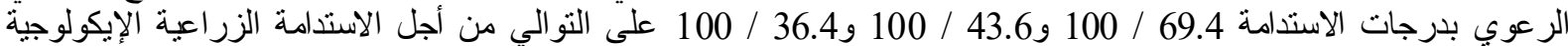

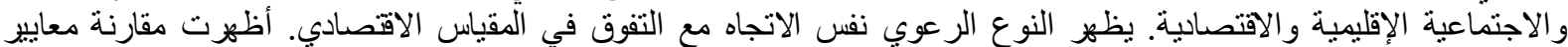

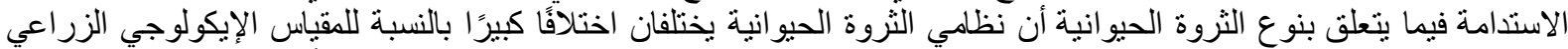

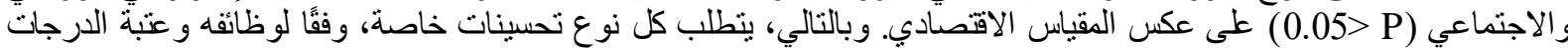

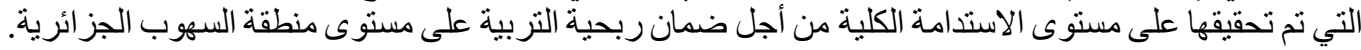
الكلمات المفتاحية: الجزائر، لحوم الضأن، الاستدامة، المؤشرات، المر اعي، السهوب. 


\section{Introduction}

Climate change has recently shown an impact on various sets of biological and physical ecosystems and its effect has made a significant change in many sectors, principally in the agricultural and livestock sector, which is the main source of livelihood for many people in arid countries (Ado et al., 2019, Yerou et al, 2021). The importance of the meat sheep farming sector in covering the growing needs of the population has been known for centuries. This livestock contributes to the maintenance of the steppe ecological system by providing an important product for human welfare (Vari- jakshapanicker et al., 2019).Livestock farming plays an important role in creating employment opportunities in arid steppe environment, as well to providing animal products to a large number of inhabitants (Yerou, 2013). Indeed, livestock production in dry lands seems to be promising despite the difficult climatic constraints (Zytoon and $\mathrm{Nu}$ - man, 2015, Yerou and al, 2021).

There is currently a strong societal demand for sustainable livestock systems. These must be respectful of the environment, economically viable for farmers, and socially acceptable. Indeed, according to Hennessy et al 2013, farm sustainability remains diffic ult to measure. Thus, the need to assess this concept has led to the development of evaluation tools ranging from indicator-based approaches (Thiol-let Scholtus and Bockstaller, 2015) to de veloped models (Paracchini et al., 2015). The lack of studies analyzing in a comprehensive way the sustainability of these farming systems led us to the realization of this study, to test and analyze sustainability of sheep meat farms in Algerian steppe environment.

The sustainability of sheep farming systems is today a major challenge in steppe areas. The main issue of this contribution is firstly scientific to produce knowledge on sheep farms in a context of climate change and socio-economic mutations of the pastoral sheep sector and secondly to test evaluation approaches, often de veloped in Western countries. From a development point of view, the aim is to characterize and improve the sustainability of steppe sheep farms. Indeed, pastoral systems are inseparable from the natural resources of the steppe rangeland, which is weakening and undergoing a significant change in its functioning (Yerou 2013). With a population of more than 28 million head of sheep, the majority of which are extensive, this type of livestock farming faces challenges that undermine its sustainability Yerou 2013. The observation made by Ghozlane et al 2008 and Yerou 2013, the development mode ls that have known the Algerian steppe, have all shown their limits, especially in the divergence between the different components of sheep farming (farmer, animal and vegetation). The breeding systems are currently evolving from a pastoral type to agro-pastoral and the food conduct is generalized by the supplementation on range. The functioning of livestock practices is marked by the mobility of sheep flocks and men within vast rangelands for collective use, constituting a fragile ecosystem where more than 3.6 million inhabitants with their ruminant flocks and exploiting free pastoral forage units (Bourbouze 2000, Bensouiah 2003 and Yerou 2013). Certainly, the balance of this steppe area is currently compromised due to management methods of pastoral resources that have difficulty adapting to multiple changes (s ocio-political; cultural and climatic hazards). For their part Aïdoud et al 2006, Köchy et al 2008, indicate that in the Maghreb countries, the degradation of steppe range lands and soils is reaching very worrying stages. The emergence of agro pastoral systems in an area traditionally reserved for grazing raises questions about its sustainability. (Ghozlane et al 2008, Bencherif 2011, Benidir 2015, Senoussi et al 2014, Hadbaoui et al 2020).

The objectives of this research are to evaluate the sustainability indicators of meat sheep farming system in eastern Algeria by use method of sustainability indicators of farms IDEA (Vilain 2003), an approach already tested in several countries, Algeria by (Ghozlane et al 2006 and 2008), Lebanon by Srour et al 2009 and in Morocco by Araba and Boughalmi 2016. This tool has shown its interest and relevance in the analysis of some indicators of sustainable development. The application of such a method required first the characterization of the farms under investigation 
by a typology.

\section{Materials and Methods}

\section{Presentation of the study region}

The pastoral vocation of the region of M'sila is very old where the livestock activity is still a source of income for a large part of the local population. This steppe ecosystem covers an area of $18,175 \mathrm{~km} 2$ (latitude $350,400 \mathrm{~N}$; longitude $040,300 \mathrm{~N}$ ) and was selected for its significant pastoral and agro pastoral potential (Figure 1).

The pastoral area represents 1.8 million hectares, of which 1 million hectares are reserved for rangelands (Hadbaoui et al 2020). The sheep population is 1.65 million (DSA 2018), so the region is characterized by considerable potential for local sheep meat. According to the HCDSHaut Commissariat au Développement de la steppe (HCDS) report 2010, the pastoral space has suffered a very severe degradation on $73 \%$ of the total area of rangelands, following an animal overload. Our monitoring focused on sheep farming systems in the southern zone of the region.

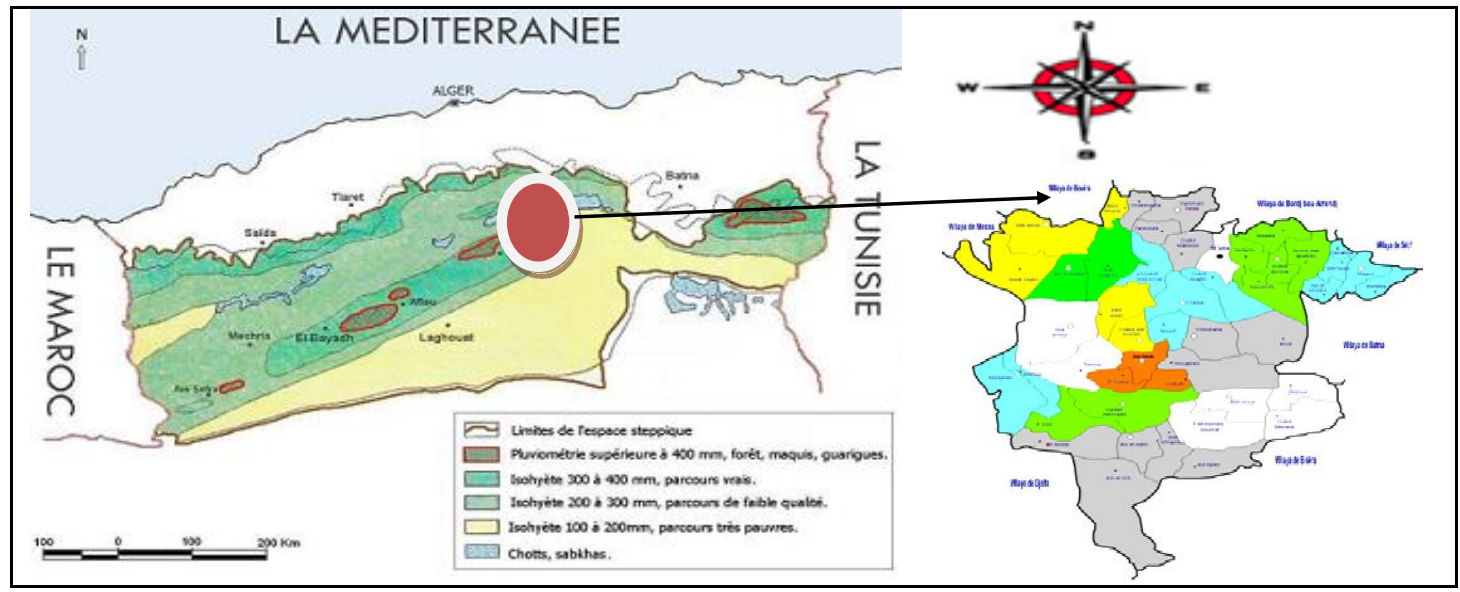

Figure 1. Geographic location of M'sila study area.

\section{Approach of the study}

Semi-structured interviews were conducted with 51 farmers, selected on the basis of structure, operating mode and livestock management practices. The objective was to evaluate the sustainability of sheep farms in the Msila region using the IDEA method (Vilain 2003). The selected farms were surveyed during the year 2018-2019. The IDEA method (indicators of sustainability of farms) version 3 is characterized, by 42 indicators structured within 10 components and three scales of sustainability: agro-ecological, socio-territorial and economic (Briquel et al 2001, Vilain 2003 and Vilain et al 2008). A questionnaire was established as a survey guide with questions related to the typological functioning of the sheep farm. It also allowed the sustainability indicators to be filled in according to the three scales. All scales have the same weight and range from 0 to 100 points. The agro-ecological scale is structured in three components of equal importance (capped at 33 and 34 points): domestic diversity (4 indicators), spatial organization ( 7 indicators) and agricultural practices (7 indicators). The socioterritorial scale refers to ethics and human development, and characterizes the integration of the farm in its territory and in society. It evaluates the quality of life of the farmer and the weight of the market or non-market services that he provides to the territory and to society. It is structured in 3 components (product quality, employment and services, ethics and human development) have the same weight and are capped at 33 on a scale of up to 100 . The economic sustainability scale analyzes economic results beyond the short term and the vagaries of the economy. Organized into 4 components, each is capped at 20 to 25 units and 6 indicators. The choice of this method is motivated by the fact that it is relatively simple and easy to implement. 


\section{Statistical analysis}

The sheep farms surveyed were characterized by multivariate statistical analysis using statistica. The calculation of the different components and their indicators was done according to the grid proposed in the IDEA method in an EXCEL table.

\section{Results and discussion}

\section{Typological characterization of farming systems}

The typological study allowed the identification of two types of livestock systems within the sample based on indicators of food resource use and structural elements of the sheep farm Table 1.

The agro-pastoral type: represents $33 \%$ of the sample, characterized by the use of agricultural resources (barley, bran, straw, hay), mainly cereals produced on the farm or purchased on the local market depending on stocks and the agricultural year. The second type is pastoral, which represents $67 \%$ of the sample, and with feeding profile based on pastoral vegetation such as free forage units on pasture and a reasoned supplementation according to critical physiological phases of ewes (struggle, late pregnancy and early lactation). Senoussi et al 2014 and Hadbaoui et al 2020 in the same region of our study reported similar results.

The determining element of the typology informs on the transformation of the feeding profile based on the integration of fodder crops and agricultural by-products for more than a third of the sample. This trend indicates the transformation of the traditional pastoral livestock system towards a new sedentary system, linked to agricultural activity and food supplementation in the form of concentrates. Several authors report similar findings for the entire territory of the Algerian steppe ecosystem (Bourbouze 2000, Yerou, 2013, Senoussi et al 2014 and Hadbaoui et al 2020).

Table 1. Distribution of livestock system types in M'sila steppe.

\begin{tabular}{ccccc}
\hline Size of herd (unit) & Number of breeders & \% & \% Agro-pastoral & \% pastoral \\
\hline$<100$ & 27 & 52,9 & 63 & 37 \\
\hline $101-150$ & 13 & 25,5 & 54 & 46 \\
\hline $151-200$ & 04 & 7,8 & 0 & 100 \\
\hline$>200$ & 07 & 13,7 & 14 & 86 \\
\hline Total & 51 & 100 & 33 & 67 \\
\hline
\end{tabular}

\section{General characterization of sustainability}

For the average farm, we obtained results for each scale. As we notice in table 2, the sustainability score of the sample being the lowest value of the three scales since it will be on this scale that the farmer will have to focus his efforts. Indeed, in our case, the overall sample is limited by the socioterritorial scale to have a sustainability score of 38.0.

Table 2. Evaluation scales and their components according to identified livestock systems.

\begin{tabular}{|c|c|c|c|c|}
\hline Type of systems & agro-ecological & socio-territorial & economic & Score Total \\
\hline Agro-pastoral & $69.4 \pm 2,06^{a}$ & $43.6 \pm 1,05^{a}$ & $36.4 \pm 1,21^{a}$ & $149.4 \pm 2,51$ \\
\hline Pastoral & $59.6 \pm 1,37^{b}$ & $32.4 \pm 0,96^{b}$ & $42.6 \pm 0,96^{a}$ & $134.6 \pm 2,51$ \\
\hline Maximum value & 100 & 100 & 100 & 300 \\
\hline Average $\pm \sigma$ & $64.5 \pm 3,02$ & $38.0 \pm 1,97$ & $39.5 \pm 1,46$ & $142 \pm 2,8$ \\
\hline
\end{tabular}

$a$ and $b$ : the difference is significant $/ P$ is significant $(P<0.05)$

The results obtained (Figure 2) showed that the sustainability of farms in the steppe zone is limited for pastoral type by the socio-territorial scale with a score of 32.4/100 and on the contrary, the agroecological scale has a score of 59.6/100, while the economic scale is around 42.6/100. The agro pastoral farms present a limit for the economic scale with a score of $36.4 / 100$ and values of $69.4 / 100$ and 43.6/100 respectively for the agro-ecological and socio-territorial scales. 

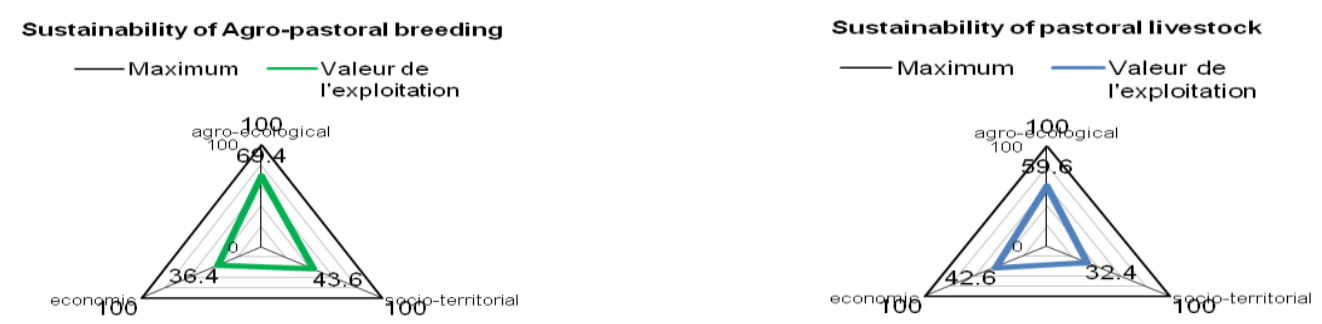

Figure. 2. Graphical representation of sustainability according to identified livestock types

\section{Agro-ecological scale}

According to Vilain, 2000, the examination of the agro ecological scale makes it possible to characterize the production systems on the aspect of autonomy in terms of use of energy and nonrenewable materials and to be less generating of pollution. The averages obtained oscillate between 12 and 25 points out of a maximum of 33 to 34 points, which gives a good appreciation of the state of the systems and their diversity, their organization of space and agricultural products for farms of the agropastoral type. In comparison with those of the pastoral type, which represents a weakness in terms of agricultural practices due to the fact that the system functions mainly on the basis of free pastoral resources. The total scores for agro-ecological sustainability represented 69.4/100 and 59.6/100 points for the agro-pastoral and pastoral type, respectively (Figure 3). These values qualify the surveyed farms as ecologically sustainable. Higher results were reported by Ghozlane et al 2008 in the sedentary farms of the steppe region of Djelfa, i.e. 82.7/100 points in total. On his side in Lebanon, Srour 2006 indicates that sedentary systems have a high score of agro ecological sustainability compared to nomadic systems.

The comparison concerning these three scales shows that the type of production system significantly affects the agro-ecological and socio-territorial scale $(\mathrm{P}<0.05)$ but not the economic scale. This difference is mainly due to the score of the "Diversity" component which is reinforced by the important animal diversity, reflected by the breeding species. In same herd, as well as by use of local breed in its cradle (Ouled Djellal and variants); and by the diversification of the pastoral resources on the floristic level which affects the pastoral value of the rangelands. Indeed, taking into account the organization of the rangeland and cultivated space can explain the differences between agro-pastoral and pastoral farms regarding the space organization component. According to, Araba and Brougham 2016, report that for the three scales of sustainability (agro-ecological, socio-territorial and economic), pastoral and agro-pastoral production systems differs significantly for agro-ecological and socioterritorial scale.

\section{Socio-territorial scale}

The indicators of the socio-territorial scale promote a set of objectives, namely quality of life, social integration, local development and coherence. A significant difference was found between the two agro-pastoral and pastoral systems $(\mathrm{P}<0.05)$, with a mean of 43.6/100 and 32.4/100 respectively. The socio-territorial sustainability of the agro-pastoral system is better than the pastoral type as a result of the score of the component "Ethics and human development" and employment and services (Figure 3). Which assesses the satisfaction of the herder with the conditions under which he carries out his activity, his participation in training, or his responsibility towards the global food balance. In addition, the two systems have similar performances for the "Quality of products and territories" component $(\mathrm{P}>0.05)$, but different for the two other components. 


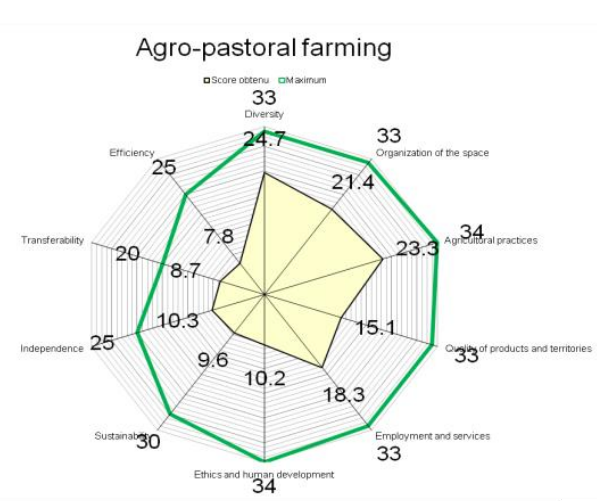

pastoral livestock

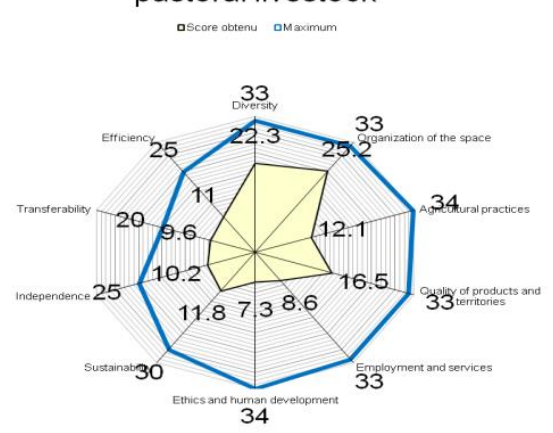

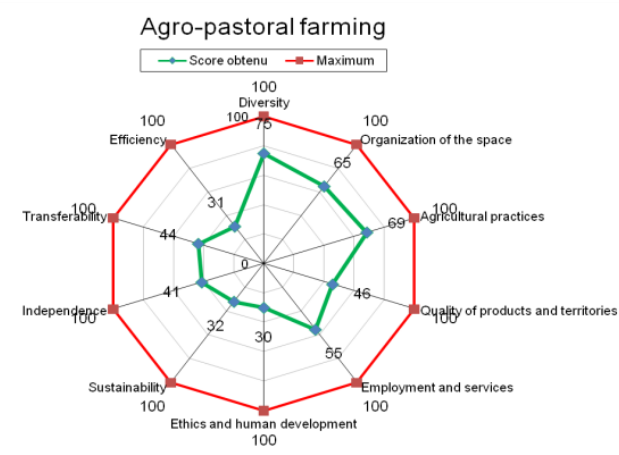

pastoral livestock

$\rightarrow$ Score obtenu $\rightarrow$-Maximum

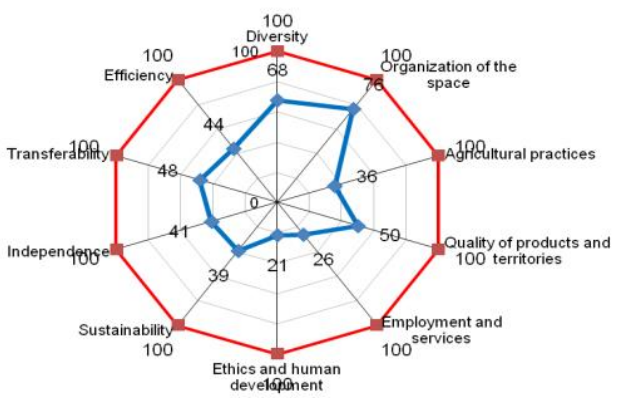

Figure 3. Representation of the components of Sustainability according to types of breeding

The production of sheep meat for slaughter for both systems, presents an advantage for that of pastoral profile, which is qualified of better biological quality compared to that of the agro-pastoral system in spite of the identity of the racial composition (breeding of the breed Ouled Djellal and variants). In general. All aspects related to product quality, to the various services rendered to the territory and to ethics are not taken into account by the breeders, who give more priority to the profitability aspect of breeding than to citizenship. In addition, there is a lack of training programs adapted to the educational levels of the farmers, a low involvement of farmers in associative structures and a strong feeling of isolation. This high value refers to the attachment of local herders to the activity of breeding despite the various constraints. Similar findings were indicated by (Mhamdi 2009, Brahmi-Mohamed et al 2019), for the sheep farming system in Tunisia, with low scores for the socio-territorial scale, reputedly due to the lack of training and the low score of the Employment and Services component. This translates into low sustainability score, which is in line with the results obtained by Gamborg and Sandøe 2003, Snoussi and M'hamdi 2008.

\section{Economic scale}

The analysis of economic indicators is based on the technical and financial orientations of the breeding system, which affect the economic results achieved. Indeed, the sustainability of a sheep meat production system depends not only on its economic viability, but also on its economic independence, its transferability and its efficiency. The economic sustainability reaches an average value of about $36.4 / 100$ and $42.6 / 100$ of the theoretical maximum for the agropastoral and pastoral system respectively (figure 3). These values are lower than those reported by Araba and Boughalmi 2016, for sheep production systems in Morocco and those of Srour et al 2006 in Lebanon. In addition, the results of the components of economic sustainability indicate that pastoral livestock achieved score superiority for all the components of the scale compared to agro-pastoral. This can be explained by the significant financial capital associated with large herd sizes for pastoral livestock. In addition, the fairly good economic efficiency of pastoral livestock reflects its independence and good management of available resources. 
This trend can be explained by the sale price of meat, which remains the highest in the Maghreb, which justifies the persistence of pastoral breeding based on commercial concentrated feed and barley for the finishing of lambs for sale. According to Bourbouze 2000, the maintenance of the use of concentrated feeds despite the high prices of cereals on the international market, is due to the ratio of the price of $\mathrm{kg}$ of live lamb / $\mathrm{kg}$ of barley. This ratio is higher than 25 because of the high price of meat, so that it takes only $10 \mathrm{~kg}$ of barley to make $1 \mathrm{~kg}$ of growth in a flock. Thus, the price of meat is about 2.5 times the price of barley needed to produce that meat.

\section{Conclusion}

Sheep farming systems in the Algerian steppe zone are faced with many challenges such as climate change, water scarcity, increasing sheep productivity at low cost and maintaining free natural resources without degradation. Indeed, the evaluation of the sustainability of these systems remains difficult to measure due to the mobility of the flocks and the vastness of the pastoral space. In this environment, the sustainability of meat sheep farming is closely linked to the balance between environmental, socio-cultural and economic aspects, which is becoming a major priority for policy makers and agricultural development institutions. The typological analysis of sheep farming has brought out a diversity of farms practicing sheep farming grouped into two types (agro pastoral and pastoral). This diversity is essentially due to the elements of livestock structure, food resources and livestock operation. The results of the scores showed that the sustainability for both agro-pastoral and pastoral livestock systems is limited by the socio-territorial and economic aspect. The results of the evaluation of the three scales of sustainability show a significant difference between the agro-pastoral and pastoral systems for some indicators. These differences reflect the variability of the functioning of the livestock and the socio-economic behavior of the herders according to their local knowledge, and their ancestral visions and perceptions of the steppe ecosystem. Each type of system has its own particularities and contributes in one way or another to the overall sustainability, which requires interventions adapted to each case. Overall, the current state of sustainability remains moderately satisfactory but requires improvement through training and extension for livestock farmers in terms of sustainable development of livestock production, in order to ensure the continu ity of this sector in the eastern steppe region of Algeria. The success of a sustainable sheep-breeding project requires the involvement of all the actors of the sheep meat sector within the pastoral environment.

\section{Acknowledgement}

We would like to thank all the breeders surveyed and the association of breeders in the Msila region for giving us the opportunity to carry out this study, as well as all the people in charge of the agricultural services department for the statistical data and the field.

\section{References}

Ado A.M. Leshan J. Savadogo P. Bo L. Shah A.A. 2019. Farmers' awareness and perception of climate change impacts: case study of Aguie district in Niger. Environment Development Sustainability, 21:2963-2977. https $/ /$ doi.org/10.1007/s10668-018-0173-4.

Aïdoud A. Le Floc'h $\mathbf{E}$ et Le Houérou H. N. 2006. Les steppes arides du nord de l'Afrique. Sécheresse $2006 ; 17$ 1-2) : 19-30. http://www.jle.com/e-docs/00/04/1F/03/ vers_alt/ VersionPDF. pdf

Araba A. Boughalmi A. 2016 Assessment of extensive and oasis sheep farming systems sustainability in Morocco. In : Napoléone M. (ed.), Ben Salem H. (ed.), Boutonnet J.P. (ed.), López-Francos A. (ed.), Gabiña D. (ed.). The value chains of Mediterranean sheep and goat products. Organisation of the industry, marketing strategies, feeding and production systems. Zaragoza : CIHEAM, 2016. p. 621-625

Benche rif S. 2011. L'élevage pastoral et la céréaliculture dans la steppe algérienne. Évolution et possibilités de développement. (Thèse de doctorat). AgroParisTech, Paris, France, 257p.

Benidir M. 2015. Evaluation multicritères de la durabilité des systèmes d'élevage ovin en zone 
steppique : Cas de la région de Djelfa. Thèse ENSA, El-Harach-Alger, 180 p.

Bensouiah R. 2003. La lutte contre la désertification dans la steppe algérienne : les raisons de l'échec

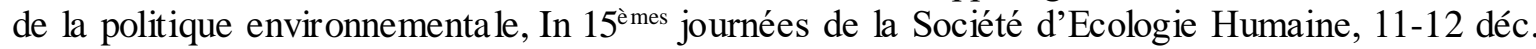
2003, Marseille. Du Nord au Sud : le recours à l'environnement, le retour des paysans http://www.afpf-asso.org/index/action/page/id/33/title/Les-articles/article/1477

Bourbouze A. 2000. Pastoralisme au Maghreb : la révolution silencieuse. Fourrages 161: 3-21.

Brahmi-Mohamed A. Mechi A. Mhamdi N. 2019 Durabilité de l'élevage ovin systèmes en Tunis ie centrale : cas de la région de Sidi Bouzid. In : Ruiz R. (ed.), López-Francos A. (ed.), López Marco L. (ed.). Innovation for sustainability in sheep and goats. Zaragoza : CIHEAM, 2019. p. 423-431 (Options Méditerranéennes : Série A. Séminaires Méditerranéens ; n. 123)

Briquel V. Vilain LJ. Bourdais L. Girardin P. Mouchet C. Viaux P 2001. La méthode IDEA (indicateurs de durabilité des exploitations agricoles) : une démarche pédagogique", Ingénieries - E A T 2001(25): 29-39.

Gamborg Ch. Sandøe P 2003. Breeding and biotechnology in farm animals: Ethical issues. In: Levinson, R.,Reiss, M. (Eds.), Key Issues in Bioethics. Routl-edge Falmer, London; 133- 142.

Ghozlane F. Yakhlef H. Allane M. Bouzida S. 2006. Evaluation de la durabilité des exploitations bovines laitières de la wilaya de Tizi-ouzou. NEW-MEDIT Volume $5 . \mathrm{N}^{\circ} 4$

Ghozlane F. Ziki B. Abbadie B. Yakhlef $\mathbf{H}$ 2008. Évaluation de la durabilité des exploitations ovines steppiques de la wilaya de Djelfa. LivestockResearch for Rural Development 20 (10) 2008

Hadbaoui I. Senoussi A. Hugue nin J 2020. Les modalités d'alimentation des troupeaux ovins en steppe algérienne, région de M'Sila : pratiques et tendances Cah. Agric., 29 (2020) 28DOI: https://doi.org/10.1051/cagri/2020027

HCDS. 2010 Haut Commissariat de Développement de la steppe. Rapport d'action. Doc. Ronéotypé, $36 \mathrm{p}$.

Hennessy T. B uckley C. Dillon E. Donnellan T. Hanrahan K. Moran B. Ryan M 2013. Measuring Farm Level Sustainability with the Teagasc National Farm Survey. Teagasc. Irland, p. 1-22.

Köchy M. Mathaj M. Jeltsch F. Malkinson D 2008. Resilience of stocking capacity to changing climate in arid to Mediterranean landscapes. Reg Environ Change 8:73-87.

M'Hamdi N. Aloulou R. Mouna Hedhly M. Ben Hamouda M 2009. Évaluation de la durabilité des exploi-tations laitières tunis iennes par la méthode IDEA, Production animale, vol. 13, no 2, p. 221228.

Paracchini M L. Bulgheroni C. Borreani G. Tabacco E. Banterle A. Bertoni D. Rossi G. Parolo G. Origgi R. De Paola C 2015. A diagnostic system to assess sustainability at a farm level: The SOS -TARE model. In: Agricultural Systems, 133, p. 35-53.

Senoussi A. Hadbaoui I. Hugue nin J 2014. L'espace pastoral dans la région de M'sila, Algérie: état et perspectives de réhabilitation. Livestock Research for Rural Development. Volume 26, Article \#206. http://www.lrrd.org//rrd26/11/seno26206.html

Srour G. Marie M. AbiSaab S 2006. Evaluation de la durabilité des élevages de petits ruminants au Liban. In: Pacheco F. (ed.), Morand-Fehr P. (ed.).Changes in sheep and goat farming systems at the beginning of the 21st century: research, tools, methods and initiatives in favour of a sustainable development . Zaragoza : CIHEAM / DRAP-Norte / FAO, 2009. p. 21-35 (Options Méditerranéennes : Série A. Séminaires Méditerranéens; n. 91)

Snoussi S. M'hamdi N 2008. L'élevage des ruminants en Tunisie : évolution et analyse de durabilité. Colloque international «Développement durable des productions animales : enjeux, évaluation et perspectives », Alger, 20-21 Avril 2008

Thiollet-Scholtus, Bockstaller C. 2015. Using indicators to assess the environmental impacts of wine growing activity: The INDIGOÂ® method. European Journal of Agronomy. Volume. 62:13-25, https:/doi.org/10.1016/j.eja.2014.09.001

Varijakshapanicker P. Mckune S. Miller L. Hen- drickx S. Balehegn M. Dahl GE. Adesogan AT. 2019 Sustainable livestock systems to im- prove human health, nutrition, and economic status. Animal Frontiers, 9(4): 39-50. https $/ /$ doi. org/10.1093/af/vfz041

Vilain L. 2003. La méthode IDEA: Indicateurs de Durabilité des Exploitations Agricoles. Guide 
d'utilisation, deuxième édition enrichie et élargie à l'arboriculture, au maraîchage et à l'horticulture, Educagri éditions, Dijon, France, p. 151.

Vilain LD. Boisset K. Girardin P. Guillaumin A. Mouchet C. Viaux P. Zahm F. Eds. 2008. La méthode IDEA : indicateurs de durabilité des exploitations agricoles : guide d'utilisation. Approches, Dijon, Educagri Editions.

Yerou H 2013. Dynamique des systèmes d'élevage ovin et leurs impacts sur l'écosystème steppique, cas de la Wilaya de Naama.Thèse doctorat Es Science. Université de Tlemcen. Algérie. 107p.

Yerou H. Homrani A. Rehal M. Ouldoulhadj H et Koudad B 2021. Impact du stress thermique sur la reproduction de brebis Hamra en zone semi-aride sud méditerranéenne. Livestock Research for Rural Development. Volume 33, Article \#70. Retrieved August8, 2021, from http://www.lrrd.org/lrrd33/5/3370houa.html

Zytoon MA. Numan AS 2015. Climate Change Indicators in the North of Jordan. Dirasat: Human and Social Sciences, 42(2): 1467-1486. 